\title{
PEMAHAMAN REMAJA TENTANG KESEHATAN REPRODUKSI (PERNIKAHAN DINI DAN PERILAKU BERESIKO) DI SAMPANG MADURA
}

\author{
Netty Dyah Kurniasari, Iswari Hariastuti, Mardiono
}

\begin{abstract}
ABSTRAK
Tujuan penelitian ini untuk mengetahui pemahaman remaja tentang kesehatan reproduksi. Beberapa indikator yang digunakan untuk mengukur adalah akses informasi remaja tentang kesehatan reproduksi, pengetahuan remaja tentang kesehatan reproduksi, sikap dan kontrol perilaku yang dihayati. Metode yang digunakan dalam penelitian ini adalah kualitatif dengan teknik pengumpulan data wawancara langsung. Lokasi penelitian di Kabupaten Sampang Madura dengan pertimbangan, angka pernikahan dini di Kabupaten tersebut termasuk tertinggi di Jawa Timur.Hasil penelitian menunjukkan bahwa pemahaman remaja tentang kesehatan reproduksi (pernikahan dini dan perilaku beresiko) rendah. Rendahnya pemahaman ini karena adat istiadat setempat, kepatuhan remaja thd orang tua dan kurangnya informasi tentang kesehatan reproduksi.
\end{abstract}

Kata kunci : kesehatan reproduksi, Madura, Remaja

\section{PENDAHULUAN}

Angka pernikahan dini sangat tinggi. Persentase perempuan yang menikah di bawah 17 tahun lebih tinggi daripada rata-rata Jawa Timur.Kabupaten Sampang berdasarkan data angka pernikahan dini juga sangat tinggi.Bisa dilihat dari tabel di bawah ini:

Tabel 1.1

Persentase Perempuan Jawa Timur Usia 10 Tahun Ke Atas yang Kawin di Bawah Umur (Kurang dari 17 Tahun) menurut Kabupaten/Kota,

\section{$2011-2013$}

\begin{tabular}{|c|c|c|c|c|c|c|}
\hline \multicolumn{2}{|c|}{$\begin{array}{l}\text { Kabupaten/ } \\
\text { Kota }\end{array}$} & \multicolumn{2}{|c|}{$\begin{array}{l}\text { Persentase } \\
\text { Perkawinan } \\
\text { tahun }\end{array}$} & $\begin{array}{l}\text { Perempu } \\
\text { Pertama }\end{array}$ & $\begin{array}{l}n \quad \text { yan } \\
\text { urang }\end{array}$ & $\begin{array}{r}\text { Usia } \\
\text { dari } 17\end{array}$ \\
\hline & & 2009 & 2010 & 2011 & 2012 & 2013 \\
\hline 1 & Bangkalan & 38,58 & 37,43 & 0,04 & 25,12 & 27,14 \\
\hline 2 & Sampang & 42,78 & 47,45 & 2,75 & 45,12 & 43,33 \\
\hline J & Pamekasan & 44,59 & 41,80 & 0,89 & 40,50 & 28,85 \\
\hline 4 & Sumenep & 48,61 & 47,79 & 5,55 & 42,53 & 45,08 \\
\hline & a Timur & 31,82 & 30,61 & 8,34 & 26,32 & 26,33 \\
\hline
\end{tabular}

\section{Sumber : BPS Jawa Timur}

Berdasarkan data RPJMN 2016 Jawa Timur menemukan problematika yang berhubungan dengan remaja antara lain Pengetahuan Kesehatan Reproduksi Remaja (KRR) di Jatim masih rendah. Hal ini ditandai dengan Indeks Pengetahuan Remaja tentang KRR masih rendah yaitu sebesar 55,3\%. Indeks Pengetahuan Masa Subur rendah juga rendah hanya 30,8\%. Lebih lanjut, indeks umur ideal menikah dan melahirkan rendah hanya 54\%. Sebaliknya, Indeks pengetahuan HIV/AIDS Remaja di Jawa timur tinggi yaitu $82,1 \%$. Begitu juga Indeks pengetahuan narkoba sangat tinggi 93,4\%.

Lebih lanjut, kasus narkoba kumulatif mulai tahun 2007-2011 sebesar 189.294 orang. Dari angka tersebut $21,5 \%$ yaitu 40.690 berumur antara 16-24 tahun. (BNN, 
2011).Pengetahuan remaja tentang PUP (Pendewasaan Usia Pernikahan) melalui majalah, surat kabar, radio cukup tinggi, sementara informasi melalui PIK $R$ masih rendah (Policy Brief Pusdu 2012). Berdasarkan latar belakang di atas,maka penelitian ini akan memfokuskan pada bagaimana persepsi dan pemahaman kesehatan reproduksi remaja di Sampang Madura.

\section{METODE PENELITIAN}

Penekanan pada kajian ini lebih pada kedalaman informasi yang diperoleh dari responden dari hasil survei. Data primer diperolah dari wawancara mendalam kepada informan. Kriteria informan penelitian ini adalah:

a. Remaja yang hamil lebih dulu (hamil sebelum menikah)

b. Remaja yang bercerai sebelum usia 20 tahun

Pemilihan responden dilakukan secara purposive. Lokasi penelitian di Kabupaten Sampang dengan teknik pengumpulan data wawancara mendalam.

Ada dua jenis data dalam kajian ini yaitu primer dan sekunder. Data primer diperoleh dari wawancara mendalam kepada informan. Data lain yaitu data sekunder yang didapat dari hasil penelitian, jurnal yang mendukung. Teknik pengumpulan data yang dilakukan adalah dengan menggunakan wawancara mendalam kepada informan dengan pemilihan purposive sampling.

\section{HASIL DAN PEMBAHASAN}

Pada bagian ini akan dipaparkan kondisi umum parameter demografi dan Keluarga Berencana di kabupaten/kota yang menjadi wilayah kajian. Adapun kabupaten/kota yang menjadi objek kajian adalah kabupaten Sampang.

\section{Gambar 3.2}

Peta Kabupaten Sampang

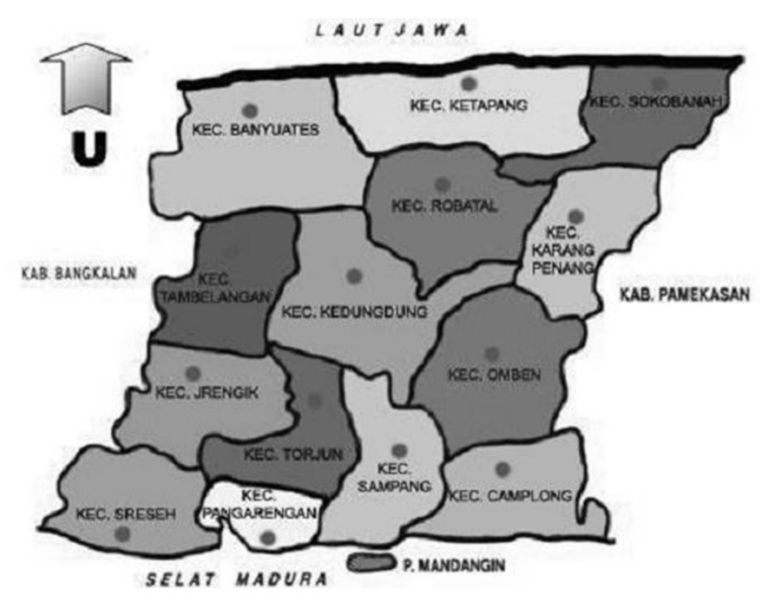

Sumber : sampangkab.go.id

Kabupaten Sampang memiliki batas batas wilayah dengan kabupaten sekitarnya sebagai berikut: Sebelah Utaraberbatasan dengan Laut Jawa; Sebelah Timur berbatasan dengan Kabupaten Pamekasan; Sebelah Selatan berbatasan dengan Selat madura; Sebelah Barat berbatasan dengan Kabupaten Bangkalan.

Jumlah penduduk Kabupaten Sampang sebanyak 877.772 berdasarkan Sensus Penduduk (SP) 2010. Dengan rincian, jumlah penduduk laki-laki sebanyak 427.896 dan penduduk perempuan sebanyak 449.876 . Banyaknya pencari kerja menurut tingkat pendidikan yang ditamatkan di tahun 2014 sebagai berikut: SLTP sederajat ke bawah 
sebanyak 5. Sedangkan tingkat SLTA sederajat sebanyak 119. Jumlah pencari kerja tingkat Diploma/Sarjana sebanyak 692. Adapun banyaknya pencari kerja yang terdaftar sebanyak 804 dan yang dapat ditempatkan sejumlah 440.Indeks Pembangunan Manusia (IPM) dari tahun ke tahun terus mengalami kenaikan. Tahun 2011 sebesar 60,78, tahun 2012 sebesar 61,03 dan tahun 2013 sebesar 62,46 .

Di Kabupaten Sampang, jumlah klinik KB sejumlah 90 tempat yang tersebar di 12 kecamatan. Jumlah kelahiran hidup di Sampang 16.936. Kematian bayi usia $<1$ tahun 2014 sebanyak 29. Angka kematian bayi (AKB) di tahun 2014 sebanyak 1,71.Petugas KB di tahun 2014 sejumlah 376 yang tersebar di 12 Kecamatan dengan rincian petugas KB dari kalangan dokter sejumlah 21 orang, petugas KB kalangan bidan sejumlah 305 dan tenaga administrasi sejumlah 50 (Sampang dalam Angka 2015). Banyaknya pasangan usia subur (PUS) tahun 2014 sejumlah 217.447. Dari jumlah tersebut, persentase peserta KB aktif sebanyak 71,82\%. Alat kontrasepsi yang paling banyak digunakan adalah suntik (97,2\%), sedangkan yang paling sedikit digunakan adalah kondom $(2,8 \%)$ (Sampang dalam Angka, 2015)

Berkaitan erat dengan kesehatan yaitu IMR (Infant Mortality Rate/IMR) atau biasa disebut Angka Kematian Bayi. IMR adalah Angka kematian bayi yaitu angka yang menunjukkan banyaknya kematian bayi (anak yang umurnya di bawah satu tahun) setiap 1000 kelahiran bayi hidup dalam satu tahun. IMR dapat dihitung dengan menggunakan rumus berikut ini :

$\operatorname{IMR}=\frac{\text { Jumlah kematian bayi umur }<1 \text { tahun }}{\text { Jumlah kelahiran bayi hidup }} \times 1000$

\section{Keterangan :}

Kriteria angka kematian bayi dibedakan menjadi berikut ini.

- IMR kurang dari 35, termasuk kriteria rendah

- IMR antara 35 sampai 75, termasuk kriteria sedang

- IMR antara 75 sampai 125, termasuk kriteria tinggi

- IMR lebih dari 125 termasuk kriteria sangat tinggi.

Menurut data yang kami peroleh dari BPS Jawa Timur, Kabupaten Sampang, mulai tahun 2009 sampai 2013 memiliki angka IMR tertinggi diantara 3 Kabupaten di Madura yaitu berturut turut 62,59 (2009), 58,92 (2010), 55,11 di tahun 2011 dan 54,48 di tahun 2012. Angka IMR di Sampang terus mengalami penurunan di tahun 2013 sebesar 51,72 dan terus turun sebesar 49,50 di tahun 2014. (BPS, Jawa Timur)

Selain IMR, faktor yang mendukung terhadap kualitas penduduk adalah TFR dan CPR. TFR atau Total Fertility Rate adalah rata-rata jumlah anak yang dilahirkan oleh seorang wanita usia subur (15-49 tahun) di suatu wilayah dalam suatu waktu tertentu. Angka TFR di Kabupaten Sampang, paling tinggi diantara kabupaten lain di Jawa Timur yaitu 2,45\%. (Susenas, 2015) . 
CPR atau Contraceptive Prevalence adalah persentase perempuan usia reproduktif yang menggunakan (atau yang pasangannya menggunakan) suatu metode kontrasepsi pada suatu waktu tertentu. CPR hampir selalu dilaporkan untuk wanita kawin atau wanita yang mmeiliki pasangan seksual. CPR dapat digunakan untuk mengukur pemakaian semua metode kontrasepsi, baik yang tradisional maupun modern, atau untuk mengukur pemakaian metode kotrasepsi modern saja. Cara menghitung CPR adalah membagi jumlah perempuan usia reproduksi (usia 15-49 tahun) yang menggunakan suatu metode kontrasepsi dengan jumlah seluruh perempuan usia 15-49 tahun, kemudian hasilnya dikali 100.

Angka CPR di Kabupaten Sampang di bawah Jawa Timur yaitu hanya sebesar $52,80 \%$. Nilai ini jauh di bawah rata -rata CPR JawaTimur yaitu sebesar 62,7 \%. Semua Kabupaten di Madura memiliki angka CPR di bawah rata-rata CPR Jawa Timur.

\section{Pemahaman Remaja Hamil di Luar Nikah tentang Pernikahan Dini dan Perilaku Beresiko}

Informan dalam penelitian ini adalah bernama FZ, dia berjenis kelamin perempuan, usianya 20 tahun. Fatimatus Zahroh adalah informan yang pernah hamil duluan (MBA). Dia sekarang sudah menikah, berjalan 1 tahun dan tidak memiliki surat nikah (Nikah Siri). Informan saat ini tidak memiliki anak, pernah mengandung tapi keguguran dikarenakan tidak kuat kandungannya. (wawancara dengan FZ November 2017)
Informan untuk mencegah kehamilannya sekarang menggunakan kontrasepsi yakni Suntik kadang memakai cara KB lain yakni susuk KB (Implant). Informan menstrusasi terakhir tanggal 11 november 2017. Informan merupakan anak pertama dan satu-satunya anak perempuan di Informan pernah mengalami tekanan dari lingkungan keluaga yakni seperti tidak boleh keluar rumah. informan tidak bebas mengekspresikan atau menyampaikan sebuah keinginannya dikarenakan malas tidak mendapat dukungan dari orang tua. (wawancara dengan FZ November 2017)

Orang tua dari Informan juga, menginginkan informan menikah di usia muda dikarenakan tidak tahu dampak dari nikah muda tersebut. Orang tua informan menginginkan dia memiliki anak di usia muda. Dalam lingkungan sosial nya seperti tetangga dan warga sekitar tidak mengecam pasangan yang berpacaran secara terbuka dikarenakan sudah biasa saja. Informan pun tidak mengetahui akibat dari nikah dini atau nikah muda dengan alasan sudah biasa di lingkungannya. Informan tidak mengerti usia ideal menikah bagi perempuan bahwa menikah kurang dari 20 tahun itu bahaya. Informan bercerita bahwa menikah di usia 20 tahun banyak terjadi pada remaja di masyarakat, dikarenakan takut tidak laku dan Informan tidak tau mendapatkan informasi dimana terkait tentang kesehatan reproduksi pada remaja khusunya untuk dirinya sendiri. (wawancara dengan FZ November 2017) 
a. Akses Informasi

Menurut informan mengetahui Fungsi organ reproduksi dari televisi dalam pengaksesan gambar pornografi informan peroleh dari media elektronik seperti internet, facebook, youtube dan lain-lain, dalam pengetahuan mengenai perilaku seks yang aman diketahui informan dari televisi, untuk pemeriksaan kehamilan, persalinan dan nifas diketahui melalui pertemuan promosi kesehatan. Dalam merawat bayi dan balita informan mengetahui dari keluarga informan sendiri, serta dalam menyusui atau memberikan ASI eksklusif diberikan dari keluarga informan sendiri. Dalam hal Pengetahuan penyakit menular seksual, seperti HIV/AIDs informan peroleh melalui televisi. Dalam hal pernikahan dini atau remaja diperoleh dari keluarga informan sendiri, Dalam hal pengetahuan cara mencegah atau menunda kehamilan (metode KB), informan peroleh dari teman dan kerabat informan sendiri. Dalam hal pola hidup sehat bagi informan tersendiri diperoleh dari keluarga informan sendiri. (wawancara dengan FZ November 2017)

b. Pengetahuan

Informan tidak mengerti usia ideal seorang perempuan untuk menikah, bahwa kalau seorang perempuan yang benar siap menikah minimal usia 21 tahun, dikarenakan di lingkungan sekitarnya banyak yang usia nya kurang dari 19 tahun sudah pada menikah. Saat di tanyakan undang-undang perkawinan mengatur batas minimal usia pernikahan yaitu perempuan 16 tahun dan laki-laki 19 tahun informan menyatakan benar. (wawancara dengan FZ November 2017)

Informan sadar bahwa menikah harus membutuhan kesiapan secara fisik, mental dan ekonomi. Informan mengetahui bahwa tanda pubertas bagi remaja wanita ialah menstruasi dan bagi laki-laki ialah mimpi basah, dan informan mengetahui pula bahwa wanita yang sudah haid, sangat berresiko hamil bila berhubungan melakukan hubungan seksual dengan lawan jenisnya. Informan mengetahui bahwa hubungan seksual meskipun hanya satu kali bisa memungkinkan menyebabkan terjadinya hamil, serta informan mengetahui perempuan yang hamil dan melahirkan di usia kurang dari 15 tahun ada resiko berbahaya. Informan juga mengetahui hal perempuan yang cukup matang menjadi seorang ibu, itu usianya diatas 20 tahun, dikarenakan sudah dewasa. (wawancara dengan FZ November 2017)

Informan juga mengalami dan membenarkan bahwa hamil di usia remaja dapat menyebabkan kesulitan seperti macet saat melahirkan, hal tersebut dialaminya saat informan masih tidak tahu kejadiannya. Dalam makanan yang tidak bergizi saat informan mengandung pada usia remajanya dapat berpengaruh terhadap janin yang ada dalam perut, hal tersebut diungkapkannya dikarenakan informan tidak mengetahui sebelumnya. (wawancara dengan FZ November 2017) 
Dalam pemahaman terkait penularan penyakit kelamin seperti HIV/AIDs, informan sudah cukup paham, seperti informan menyatakan salah bahwa penyakit HIV/AIDS menular bila berciuman dengan penderita karena hanya yang terluka saja. Dalam Penyakit raja singa seperti ( sipilis ) adalah penyakit kelamin yang bisa sembuh sendiri dinyatakan salah oleh informan dikarenakan informan tidak mengetahui apa itu raja singa atau sipilis. Informan juga membenarkan bahwa dalam penggunaan kondom itu aman karena dapat mencegah penyakit infeksi yang di tularkan melalui hubungan seksual. (wawancara dengan FZ November 2017)

Informan juga membenarkan bahwa Penggunaan alat kontrasepsi boleh dilaku-kan oleh remaja yang belum menikah dikarenakan biar pasangannya tidak hamil.Informan juga tidak mengetahui bahwa ada ketersediaan alat kontrasepsi lakilaki untuk menunda atau mencegah kehamilan. Informan tidak membenarkan bahwa pola hidup sehat hanya perlu di lakukan yang sudah berusia tua saja, bagi yang berusia muda juga diperlukan hal tersebut. Pemahaman informan terkait konseling tentang kesehatan reproduksi hanya bisa dilakukan oleh petugas kesehatan saja itu benar dikarenaka yang paham dan lebih mengerti tentang kesehatan reproduksi tersebut. (wawancara dengan FZ November 2017) c. Sikap

Menurut informan, dia setujumelihat gambar atau film porno merupakan hal yang wajar bagi remaja. Menikah di usia muda (kurang dari usia 20 tahun)juga menjadi pilihanbagi informan. Menurut informan, dia setuju bila remaja hamil mendorong dilakukannya aborsi atau pengguguran kandungan. Lebih lanjut, menurutnya, kehamilan di usia remaja lebih menyehatkan calon bayi. (wawancara dengan FZ November 2017)

Remaja putri yang baik menurut pan-dangan informan ialah yang masih perawan saat menikah, tahun dapat membahayakan jiwa ibu saat melahirkan, punya anak dengan jumlah yang banyak sangat membanggakan, kehamilan perlu di rencanakan dengan meng-ikuti program KB (keluarga berencana), remaja yang hamil di luar nikah harus segera di nikahkan, berbagai pengalaman dengan teman sebaya sangat bermanfaat. terkena penyakit kelamin sangat menjijikan. (wawancara dengan FZ November 2017)

Adapun pernyataan yang tidak setuju terkait sikap bila yang di lakukan informan, seperti: Tidak masalah menikah meskipun tidak memiliki penghasilan, pacaran hanya boleh bergandengan tangan saja, hubungan seksual di luar nikah merupakan perbuatan yang memalukan, belum menikah pada usia lebih dari 19 tahun menjadi cemooh masyarakat, pemeriksaan kehamilan tidak 
harus dilakukan bila ibu hamil sehat, remaja bermasalah sebaiknya konsultasi kepada siapapun dan saya tidak takut terhadap HIV/AIDS. (wawancara dengan FZ November 2017)

d. Norma subjektif

Dalam norma subjektif merupakan persepsi dari informan mengenai tekanan sosial untuk melakukan atau tidak melakukan perilaku. Informan berpersepsi setuju dalam pernyataan bahwa teman teman sebayanya akan mendukung dirinya bila informan tersebut memiliki pacar, kemudian masyarakat desa beranggapan bahwa semakin cepat menikah semakin baik pula, meskipun belum lulus sekolah serta remaja yang sudah memiliki anak bisa membanggakan orang tuanya karena bisa memberikan keturunan baru di keluargannya. (wawancara dengan FZ November 2017)

Adapun pernyataan yang tidak setuju terkait pernyataan bila yang di lakukan informan, seperti :orang tua melarang saya untuk berpacaran, guru tidak keberatan bila murid memiliki pacar, adat setempat menentang mudamudi yang berpacaran, masyarakat desa mendukung pasangan yang menikah pada usia muda atau remaja, keluarga mendukung secara ekonomi anak yang menikah dini tapi belum berpenghasilan, Orang tua saya melarang ikut KB (Keluarga berencana), Petugas kesehatan adalah penentu seseorang memilih jenis KB, Keluaga tidak keberatan bahwa informan melahirkan dirumah, Masyarakat membantu merujuk saat ibu hamil mendapatkan kesulitan saat melahirkan, dan masyarakat mencela remaja yang hamil sebelum menikah. (wawancara dengan FZ November 2017)

e. Kontrol perilaku yang dihayati

Dalam kontrol perilaku yang dihayati ini informan ditentukan oleh pengalaman masa lalunya dan perkiraan informan mengenai seberapa sulit atau mudahnya untuk melakukan perilaku informan tersendiri, yang menyatakan pernyataan bahwa informan masih sulit dalam menentukan usia menikah yang di atas 19 tahun dan informan tidak mau menikah tanpa persetujuan dari orang tua. (wawancara dengan FZ November 2017)

Serta informan masihragu dalam hal menolak berpacaran, juga informan tidak menikah muda meskipun informan sudah memiliki pacar, informan tidak akan menikah muda meskipun banyak teman yang sudah menikah, kehamilan informan atau dari hasil pasangan diperiksakan ke dokter atau bidan. (wawancara dengan FZ November 2017)

Dalam hal kontrol perilaku yang diha-yati informan yang mudah dilakukannya diantaranya Pernikahan tidak menghalangi keinginan informan untuk melanjutkan sebuah pendidikan 
atau sekolah, kemudia informan meminta bantuan dari bidan untuk menolong kelahiran anak nya, informan memberikan asi eksklusif kepada bayinya, anak dari informan akan dilahirkan di fasilitas ranah kesehatan, bukan di rumah, informan akan mengkontrol perilaku dengan menunda memiliki anak mengikuti program KB (Keluarga berencana), dan informan yakin bahwa dirinya bisa men-jadi orang tua yang baik meskipun di usia yang masih muda. (wawancara dengan FZ November 2017)

\section{Pemahaman Remaja Cerai di bawah usia 20 tahun tentang Pernikahan Dini dan Perilaku Beresiko}

Informan dalam penelitian ini adalah bernama $\mathrm{SV}$, dia berjenis kelamin perempuan, usianya 20 tahun. SV adalah informan yang pernah Cerai dibawah usia 20 tahun. Dia sekarang sudah menyandang status janda, dari pernikahannya berjalan 1 tahun dan tidak memiliki surat nikah (Nikah Siri). Informan saat ini tidak memiliki anak, pernah mengandung tapi keguguran dikarenakan tidak kuat kandungannya. Informan untuk mencegah kehamilannya sekarang tidak menggunakan alat kontrasepsi lainya. Informan menstrusasi terakhir tanggal 20 november 2017, Informan merupakan anak pertama dan tidak satu-satunya anak perempuan di keluarganya.

a. Karakteristik Informan :

Informan tidak pernah atau
tidak sedang mengalami tekanan

dari lingkungan keluaga. informan tidak bebas mengekspresikan atau menyampaikan sebuah keinginannya dikarenakan informas tidak banyak bicara. Orang tua dari Informan juga, tidak menginginkan informan menikah di usia muda dikarenakan informan ingin menikmati masa mudanya dahulu, yang orang tua tidak inginkan dari informan saat ini yaitu menikah muda dari informan karena orang tua dari informan tidak mau melihat anaknya hidup dalam kesusahan dan orang tua informan mengecam bahwa ada pasangan muda-mudi yang hamil di luar nikah. .(wawancara dengan SV,November 2017)

Dalam lingkungan sosial nya seperti tetangga dan warga sekitar mengecam pasangan yang berpacaran secara terbuka dikarenakan tidak sepantasnya. Informan pun mengetahui akibat dari nikah dini atau nikah muda. Informan mengerti usia ideal menikah bagi perempuan bahwa menikah kurang dari 20 tahun itu tidak ideal. Informan menyatakan bahwa menikah di usia 20 tahun banyak terjadi pada remaja di masyarakat, dikarenakan takut tidak laku dan Informan mengetahui untuk mendapatkan informasi dimana terkait tentang kesehatan reproduksi pada remaja khusunya untuk dirinya sendiri. (wawancara dengan SV,November 2017)

b. Akses Informasi

Menurut informan mengetahui Fungsi organ reproduksi dari televisi 
dan dalam peng aksesan gambar pornografi informan peroleh dari media elektronik seperti internet, facebook, youtube dan lain-lain, serta dalam pengetahuan mengenai perilaku seks yang aman diketahui informan dari media elektronik seperti internet, facebook, youtube dan lain-lain, terkait untuk pemeriksaan kehamilan, persalinan dan nifas informan diketahui melalui pertemuan promosi kesehatan. Dalam hal merawat bayi dan balita informan mengetahui dari televisi, serta dalam menyusui atau memberikan ASI eksklusif diberikan dari televisi. Dalam hal Pengetahuan penyakit menular seksual, seperti HIV/AIDs informan peroleh dari televisi. Dalam hal pernikahan dini atau remaja diperoleh informan dari televisi, terkait dalam hal pengetahuan cara mencegah atau pertemuan promosi kesehatan yang pernah di ikuti informan dan dalam hal pola hidup sehat bagi informan tersendiri diperoleh dari keluarga televisi yang pernah di tontonnya. (wawancara dengan SV, November 2017)

c. Pengetahuan

Informan mengerti usia ideal seorang perempuan untuk menikah, bahwa seorang perempuan yang benar siap menikah minimal usia 21 tahun, dikarenakan kurang dewasa dalam berbagai hal. Saat di tanyakan undang-undang perkawinan mengatur batas minimal usia pernikahan yaitu perempuan 16 tahun dan laki-laki 19 tahun informan menyatakan salah, dikarenakan informan tidak mengetahui undang-undang tersebut. Informan sadar bahwa menikah harus membutuhan kesiapan secara fisik, mental dan ekonomi dikarenakan sudah dewasa. Informan mengetahui bahwa tanda pubertas bagi remaja wanita ialah menstruasi dan bagi laki-laki ialah mimpi basah, dan informan mengetahui pula bahwa wanita yang sudah haid, sangat berresiko hamil bila berhubungan melakukan hubungan seksual dengan lawan jenisnya. .(wawancara dengan SV, November 2017)

Informan mengetahui bahwa hubungan seksual meskipun hanya satu kali bisa memungkinkan menyebabkan terjadinya hamil, serta informan mengetahui perempuan yang hamil dan melahirkan di usia kurang dari 15 tahun ada resiko berbahaya. Informan juga mengetahui hal perempuan yang cukup matang menjadi seorang ibu, itu usianya diatas 20 tahun, dikarenakan sudah dewasa, Informan juga mengalami dan membenarkan bahwa hamil di usia remaja dapat menyebabkan kesulitan seperti macet saat melahirkan, hal tersebut dialaminya saat informan masih tidak tahu kejadiannya. (wawancara dengan SV, November 2017)

Dalam makanan yang tidak bergizi saat informan mengandung pada usia remajanya dapat berpengatuh terhadap janin yang ada dalam perut, hal tersebut diungkapkannya dikarenakan informan tidak mengetahui sebe-lumnya. Dalam pemahaman terkait penularan penyakit 
kelamin seperti HIV/AIDs, informan sudah cukup paham, seperti informan menya-takan salah bahwa penyakit HIV/ AIDS menular bila berciuman dengan penderita karena hanya yang terluka saja. Dalam Penyakit raja singa seperti ( sipilis ) adalah penyakit kelamin yang bisa sembuh sendiri dinyatakan salah oleh informan dikarenakan informan tidak mengetahui apa itu raja singa atau sipilis. Informan juga membenarkan bahwa dalam penggunaan kondom itu aman karena dapat mencegah penyakit infeksi yang di tularkan melalui hubungan seksual. .(wawancara dengan SV, November 2017)

Informan juga membenarkan bahwa Penggunaan alat kontrasepsi tidak benar bila dilakukan oleh remaja yang belum menikah. Informan juga mengetahui bahwa ada ketersediaan alat kontrasepsi laki-laki untuk menunda atau mencegah kehamilan. Informan tidak membenarkan bahwa pola hidup sehat hanya perlu di lakukan yang sudah berusia tua saja, bagi yang berusia muda juga diperlukan hal tersebut. Pemahaman informan terkait konseling tentang kesehatan reproduksi tidak hanya bisa dilakukan oleh petugas kesehatan saja dikarenakan bisa dilakukan oleh keluarga terdekat informan tersendiri. (wawancara dengan SV, November 2017)

d. Sikap

Dalam sikap ini merupakan pernyataan evaluatif informan terhadap objek. pernyataan yang dinyatakan terkait olehnya yaitu setuju bila informan, diantaranya: menikah di usia muda yang kurang dari usia 20 tahun yang menjadi pilihan informan tersendiri,hubungan seksual di luar nikah merupakan perbuatan yang memalukan, kehamilan di usia remaja lebih menyehatkan calon bayi, hamil di usia remaja kurang dari 20 tahun dapat membahayakan jiwa ibu saat melahirkan, pemeriksaan kehamilan tidak harus dilakukan bila ibu hamil sehat,punya anak dengan jumlah yang banyak sangat membanggakan, kehamilan perlu di rencana-kan dengan mengikuti program KB (keluarga berencana),remaja yang hamil di luar nikah harus segera di nikahkan, berbagai pengalaman dengan teman sebaya sangat bermanfaat, dan terkena penyakit kelamin sangat menjijikan. .(wawancara dengan SV, November 2017)

Adapun pernyataan yang tidak setuju terkait sikap bila yang di lakukan informan, seperti: Melihat gambar atau film porno merupakan hal yang wajar bagi usia remaja, Tidak masalah menikah meskipun tidak memiliki penghasilan, pacaran hanya boleh bergandengan tangan saja, remaja putri yang baik menurut pandangan informan ialah yang masih perawan saat menikah, hamil pada remaja mendorong dilakukannya aborsi atau pengguguran kandungan. Belum menikah pada usia lebih dari 19 tahun menjadi cemooh masyarakat, remaja bermasalah sebaiknya konsultasi kepada siapapun dan informan tidak takut 
terhadap HIV/AIDS. .(wawancara dengan SV, November 2017)

e. Norma subjektif

Dalam norma subjektif merupakan persepsi dari informan mengenai tekanan sosial untuk melakukan atau tidak melakukan perilaku. Informan berpersepsi setuju dalam pernyataan bahwa teman teman sebayanya akan mendukung dirinya bila informan tersebut memiliki pacar, masyarakat desa mendukung pasangan yang menikah pada usia muda atau remaja, Petugas kesehatan adalah penentu seseorang memilih jenis KB, Keluarga tidak keberatan saya melahirkan di rumah, Masyarakat membantu merujuk saat ibu hamil mendapat kesulitan saat melahirkan, remaja yang sudah memiliki anak membanggakan orang tuanya karena bisa memberikan keturunan baru di keluargannya. .(wawancara dengan SV, November 2017)

Adapun pernyataan yang tidak setuju terkait pernyataan bila yang di lakukan informan, seperti: orang tua melarang informan untuk berpacaran, guru tidak keberatan bila murid memiliki pacar, adat setempat menentang mudamudi yang berpacaran, masyarakat desa beranggapan bahwa semakin cepat menikah semakin baik pula, meskipun belum lulus sekolah, keluarga mendukung secara ekonomi anak yang menikah dini tapi belum berpenghasilan, Orang tua saya melarang ikut KB (Keluarga berencana), serta masyarakat mencela remaja yang hamil sebelum menikah.(wawancara dengan SV, November 2017)

f. Kontrol perilaku yang dihayati

Dalam kontrol perilaku yang dihayati ini informan ditentukan oleh pengalaman masa lalunya dan perkiraan informan mengenai seberapa sulit atau mudahnya untuk melakukan perilaku informan tersendiri, yang menyatakan pernyataan bahwa informan masih sulit dalam dalam hal menolak berpacaran. informan masih ragu, dalam hal bahwa tidak menikah muda meskipun informan tersebut sudah mempunyai pacar. Dalam hal kontrol perilaku yang dihayati informan yang mudah dilakukannya diantaranyainforman mudah menentukan usia menikah yang di atas 19 tahun dan informan tidak mau menikah tanpa persetujuan dari orang tua, Serta informan tidak akan menikah muda meskipun banyak teman yang sudah menikah, Pernikahan tidak menghalangi keinginan informan untuk melanjutkan sebuah pendidikan atau sekolah, kehamilan informan atau dari hasil pasangan diperiksakan ke dokter atau bidan, kemudian informan meminta bantuan dari bidan untuk menolong kelahiran anak nya, informan memberikan asi eksklusif kepada bayinya, anak dari informan akan dilahirkan di fasilitas ranah kesehatan, bukan di rumah, informan akan mengkontrol perilaku dengan menunda memiliki anak dengan mengikuti program KB (Keluarga berencana), dan informan 
yakin bahwa dirinya bisa menjadi orang tua yang baik meskipun di usianya yang masih muda. .(wawancara dengan SV,November 2017)

\section{KESIMPULAN}

1. Rendahnya pengetahuan remaja tentang kesehatan reproduksi disebabkan karena:

a. Kepatuhan mereka untuk menikah di usia muda jika itu permintaan orang tua

b. Kepatuhan remaja untuk tidak ikut $\mathrm{KB}$ atas jika itu diminta orang tuanya.

c. Kepatuhan remaja untuk melahirkan di rumah, tidak di rumah sakit atau puskesmas.

d. Remaja setuju dengan norma 'Remaja yang sudah memiliki anak membanggakan orang tua' --pernikahan dini

e. Remaja tidak mendapatkan informasi kesehatan reproduksi dari orang tuanya tapi dari media (internet, facebook) dll

f. Remaja setuju dengan nikah dini

2. Perilaku beresiko bisa (pacaran dan narkoba) bisa ditekan karena adanya norma setempat yang tegas.

3. Rendahnya Pengetahuan tentang kelompok teman sebaya sebagai aktor sosialisasi kesehatan reproduksi
BNN 2011

Jatim. Bps.go. id

Google.image.com

Policy Brief Pusdu 2012

Sampangkab.go.id

Sampang dalam Angka 2015

Susenas, 2015

Wawancara dengan FZ ( 20 tahun) November 2017

Wawancara dengan SV (20 tahun) November 2017

\section{DAFTAR PUSTAKA}

BPS, Jawa Timur 